\title{
Designing the Invention House Assessment Form for Kuala Krai, Malaysia
}

\author{
Thuraiya Mohd'1, Mohamad Haizam Mohamed Saraf1', \\ Siti Fairuz Che Pin ${ }^{1}$, Mohd Nasurudin Hasbullah² \\ 1 Department of Real Estate Management, ${ }^{2}$ Department of Architecture, \\ Faculty of Architecture, Planning and Surveying, \\ Universiti Teknologi MARA, Perak, Malaysia \\ thura231@perak.uitm.edu.my
}

\begin{abstract}
Floods can cause damage to homes. Some houses which have been significantly damaged, destroyed, or inhabitable. Inherently, victims should be given temporary or permanent houses depending on the degree of damage to their houses. Therefore, an assessment of the degree of house damage must be carried out as a direction for the recovery effort. Thus, this research seeks to design a House Damage Assessment Form. This form has been established by having an in-depth interview with experts involved in MERCY Malaysia and a literature review of the evaluation forms used by other countries to assess the degree of house damage post-disaster.
\end{abstract}

Keywords: flood; degree of house damage; damage assessment; post flooding

eISSN 2398-4279 @ 2018. The Authors. Published for AMER ABRA cE-Bs by e-International Publishing House, Ltd., UK. This is an open access article under the CC BY-NC-ND license (http://creativecommons.org/licenses/by$n c-n d / 4.0 /$ ). Peer-review under responsibility of AMER (Association of Malaysian Environment-Behaviour Researchers), ABRA (Association of Behavioural Researchers on Asians) and cE-Bs (Centre for EnvironmentBehaviour Studies), Faculty of Architecture, Planning \& Surveying, Universiti Teknologi MARA, Malaysia. https://doi.org/10.21834/ajqol.v3i11.121 


\subsection{Introduction}

The past few decades have witnessed a rapid expansion of population in Malaysia. The population was $10,881,000$ in 1970 but in 2013, the statistics indicated that the population in Malaysia has risen to $29,947,600$ (Malaysian Department of Statistics, 2015). The increasing population has also resulted in an increase in the number of property ownership. Therefore, a greater percentage of the country's land area, often in areas that previously were seen as being unsuitable for urban development and human settlement, are taken up to cater to the need for accommodation (Eves and Wilkinson, 2014). This increased number of properties, changes in water collection and flows and poor drainage system coupled with heavy monsoon rainfall, intense convection rain storms and other local factors have caused seasonal floods in Malaysia (Chan, 1995; Eves and Wilkinson, 2014). Following such disaster, there is often a tally of the preliminary damage assessment in respect to the injuries, loss of lives, cost of damage and destroyed properties. With these disasters attracting considerable media attention, people are more aware of the damage that occurred at the affected area. There have been numerous studies pertaining preliminary damage assessment to buildings after a flood. In tandem, there are also many ways of assessing damage that have been carried out in different countries after the event of natural disasters.

There are several guidelines for assessing the degree of building damage which are prepared by government agencies, researchers, local authorities and non-governmental organizations (NGO). In 2009, Attaullah Shah, Hamid Mumtaz Khan and Ehsan U. Qazi outlined the evaluation of the buildings destroyed or damaged due to flooding in Pakistan. The evaluation of damage is made on mud houses which are the most common type of building structure in Pakistan (Shah A, Khan, H, M. and Qazi E, U., 2009). In USA, Federal Emergency Management Agency (FEMA) has developed an operations manual to standardize the procedures in preliminary damage assessment nationwide. There are several state authorities in USA, like New Jersey and Florida, which reviewed this operations manual and did some modification to suit the type of disasters that their states often receive. Apart from that, there are also many literature that emphasized on residential properties damaged from hurricanes and floods (Hodde B. H, 2012; Federal Emergency Management Agency of USA, 2012). Different countries are likely to have different degree of housing damage. It is because, it has different construction methods, materials used and the nature of the flood disaster. In fact, in Malaysia, there is still no standardized damage assessment used by the authorities or relevant agencies in assessing the degree of housing damages after a disaster. As a result, errors in assessing the degrees of housing damages and providing inaccurate type of assistance may occur. Therefore, the first objective in this research is to design a Housing Damage Assessment Form.

The form will be used to achieve next objective which is to identify the number of houses damage in the affected area. The area of focus in this research is Kuala Krai, in the state of Kelantan. This research is an expansion of an empirical study conducted earlier on determining a model on the degree of house damage for the flood affected area in Kuala Krai. Hence, with the model of the degree of house damage that has been developed, this paper will discuss the formation of the invention House Damage Assessment Form. This form has been established by conducting an in-depth interview with five (5) experts involved in 
MERCY Malaysia to assess the house damage post flooding. Besides, a literature review on the evaluation, observation for assessment forms used by other countries to assess the degree of house damage post-disaster was also undertaken. The modifications and improvements have been made to suit with the flood disasters and building structures in Malaysia.

\subsection{Literature Review}

Many ways of damage assessment been carried out from different countries after the event of natural disaster. There are several guidelines for assessing the degree of building damage prepared by government agencies, researchers, local authorities and non-governmental organizations (NGO). In concordance with the variety of the damage assessment forms, different countries likely to have different construction methods, materials used and the nature of the flood disaster. The following damage assessment forms are laid down as the following.

\subsection{Federal Emergency Management Agency (FEMA) Revised Model of Damage Assessment Operations Manual (2012)}

This operations manual was developed by FEMA to standardize the procedures in preliminary damage assessments nationwide. This manual was prepared and reviewed by FEMA regional officers with major experience in performing damage assessment through many types of disasters. The damage assessment operations manual consists of three pages and is designed in open-ended questions. The assessment requires the respondent to provide information such as name, mailing and current address or shelter place, number of occupants, income level, contact number, location, type of incident and the description of the incident. Information on housing such as type of building structure, in-house water level, and degree of property damage are also required. There are also special information that are needed for the assessment such as insurance information, dollar damage estimation and the house status whether the house is owned or rented.

\subsection{New Jersey State Police Office Emergency Management}

New Jersey State Police Office of Emergency Management produced a preliminary damage assessment in any event of natural disasters, especially in the event of hurricane. The preliminary damage assessment is one page and designed in table form that only requires street name, house number, victim name, country, telephone number, disaster type and areas of damage. The form lacks information in term of degree of house damage, land and house status and the photograph of the affected house.

\subsection{Green Alert Damage Assessment Manual}

Damage assessment Manual by www.GreenAlert.net was based on Windshield Survey in 2004 that provides information to determine the severity of the disaster and type of disaster assistance that may be required. This damage assessment manual consists of country where the damaged is located, city, type of incident, team members (assessors), date of the 
incident, date of the survey, reference number, name of the occupants, street address, contact number, type of family structure and building structure, water level in structure, damage category, estimated damage loss, house status (own/rent), anticipated insurance and amount of insured and uninsured loss.

\subsection{State of Florida Division Emergency Management}

In Florida, as it is vulnerable to a host of natural and man-made disasters, local governments may contact Florida Department of Community Affairs, Division of Emergency Management to initiate assistance for damage assessment. Immediately following a disaster, an initial damage assessment must be carried out by them to estimate the type and extent of damages. The damage assessment is designed in table form and requires less information if compared to FEMA damage assessment operations manual. The information are type of disaster, city, country, state, date, address of the affected house, number of occupants and degree of damage.

\subsection{National Disaster Management Agency of Indonesia (BNBP)}

In the event of natural disaster in Indonesia, especially earthquakes come before flooding; The National Disaster Management Agency (BNPB) will lead in coordinating and facilitating the recovery, reconstruction and rehabilitation. Preliminary damage and needs assessment are necessary in the delivery of assistance addressing the specific needs for particular vulnerable groups of affected victims. In assessing the damage, the information require for the assessment are asset description such as asset owner name, address, contact number, location. Description of damages is also required and the photograph of the affected asset must be attached for evidence. In addition, insurance coverage must also be obtained from the respondent whether the asset is covered in part or whole. If there is no insurance, detail previous assessment of cost-effectiveness and rationale applied for not insured the damaged asset must be applied. The form also requires if the asset need for reconstruction or different type of assistance. However, the form does not require any information on land status and there is no description of each category of damage to assist the assessor in the assessment process.

\subsection{Methodology}

This research applies the triangulation approach in designing the Housing Damage Assessment Form in the Malaysia context. Several established damage assessment forms from different countries were reviewed to achieve Objective 1. Backed by observation, focus groups and personal discussions with assessors involved in house damage assessment were carried out. As a result of this, some modifications and improvements have been made to suit the form with flood disasters and building structures in Malaysia. In order to obtain validation of the proposed housing damage assessment form, it has been validated by five (5) experts involved in MERCY Malaysia through an in-depth interview to assess the housing damage after a disaster.

To achieve Objective 2, survey observation and informal interviews were 
conducted at the case study area, that is, along Sungai Krai which includes Jalan Geale B, Geale C, Geale C2, Geale C3, Geale C4 and Geale D which are all located in the District of Tualang territories. Observation on all damaged houses at the affected area was conducted and the total number of houses involved was 223. Informal interviews were carried out with the owners or households of the affected houses. The respondents were selected based on the convenience sampling technique. The data were tabulated into percentages and frequency distribution form for univariate analysis.

\subsection{Limitations}

Due to limitations in term of constrained time and limited costing, this research only focuses at the highest number of affected houses in Kelantan, which is in Kuala Krai with 1,850 units.

\section{HOUSING DAMAGE ASSESSMENT FORM}

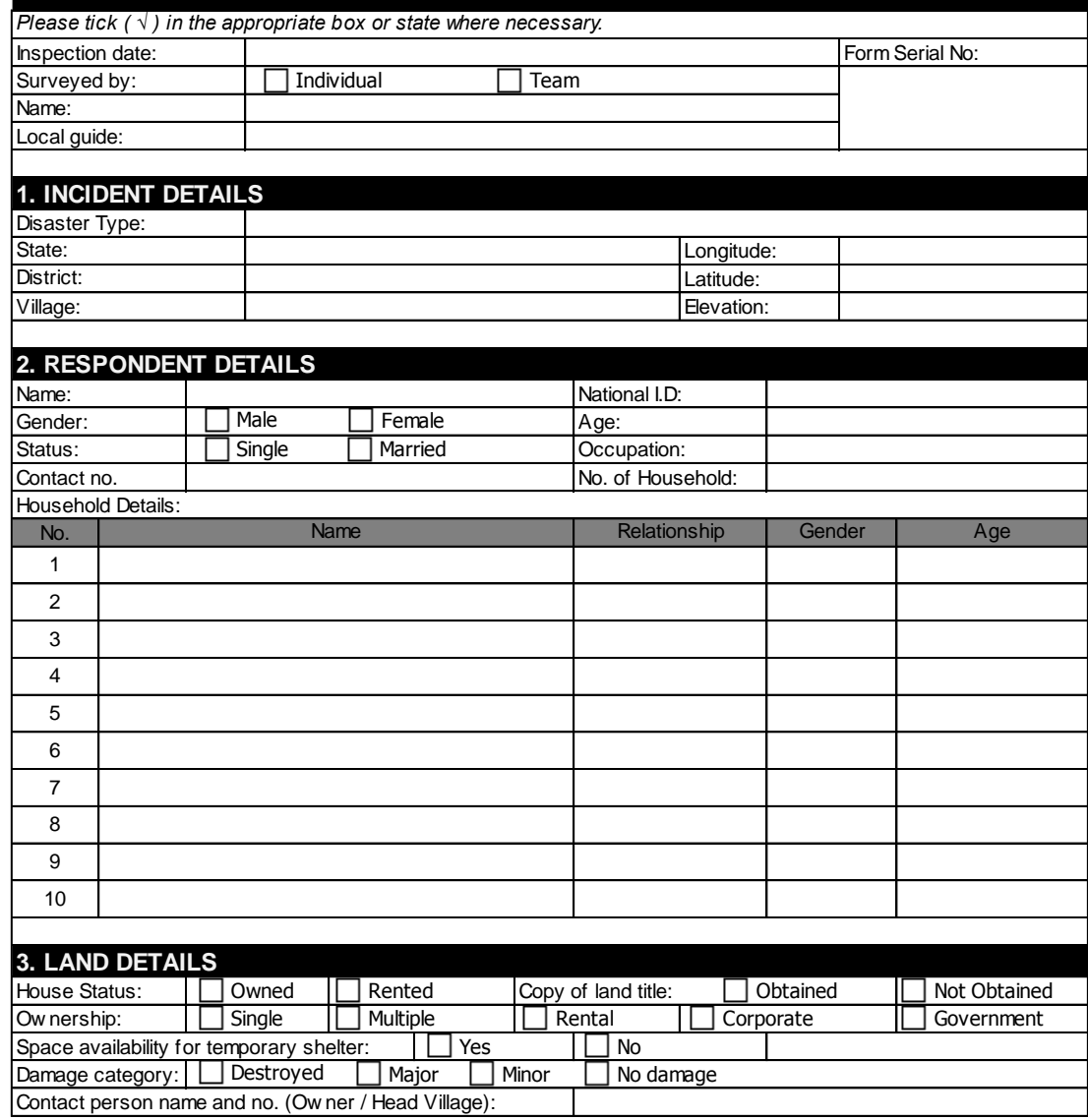


Mohd. T., et.al. / Asian Journal of Quality of Life (AjQoL), 3(11) May / Jun 2018 (p.47-57)

\begin{tabular}{|c|c|c|c|c|c|}
\hline \multicolumn{6}{|c|}{ 4. DAMAGE ASSESSMENT } \\
\hline $\begin{array}{l}\text { Degree of } \\
\text { Damage }\end{array}$ & Description of Damage & \multicolumn{2}{|c|}{ Attributes of Damage } & \multicolumn{2}{|c|}{ Recommendation } \\
\hline \multirow[t]{2}{*}{ Minor } & \multirow{2}{*}{$\begin{array}{l}\text { Slight damage to building structure, } \\
\text { can be occupied w ithin a short } \\
\text { period after minor reparation. }\end{array}$} & $\square$ & $\begin{array}{l}\text { Minor damage in partitions, } \\
\text { infills and ceilings }\end{array}$ & $\square$ & $\begin{array}{l}\text { Immediate action for } \\
\text { building repair kit }\end{array}$ \\
\hline & & $\square$ & $\begin{array}{l}\text { Minor damage to door and } \\
\text { w indow s }\end{array}$ & $\square$ & $\begin{array}{l}\text { Habitable after minor } \\
\text { repairs w hich take } \\
\text { less than } 30 \text { days }\end{array}$ \\
\hline \multirow[t]{2}{*}{ Major } & \multirow{2}{*}{$\begin{array}{l}\text { The building has sustained } \\
\text { structural or significant damages, } \\
\text { inhabitable and requires extensive } \\
\text { repairs. }\end{array}$} & $\square$ & $\begin{array}{l}\text { Substantial failure of } w \text { alls, } \\
\text { floors, foundation or roof. }\end{array}$ & $\square$ & $\begin{array}{l}\text { Require temporary } \\
\text { shelter }\end{array}$ \\
\hline & & $\square$ & $\begin{array}{l}\text { Utilities damaged (Electrical, } \\
\text { Surface w ater drainage, }\end{array}$ & $\square$ & $\begin{array}{l}\text { Habitable after } \\
\text { extensive repairs }\end{array}$ \\
\hline \multirow[t]{2}{*}{ Destroyed } & \multirow{2}{*}{$\begin{array}{l}\text { The building structural is } \\
\text { permenantly uninhabitable and } \\
\text { requires demolition. }\end{array}$} & \multirow[t]{2}{*}{$\square$} & \multirow[t]{2}{*}{$\begin{array}{l}\text { The building structure is total } \\
\text { loss }\end{array}$} & $\square$ & $\begin{array}{l}\text { Require temporary } \\
\text { shelter }\end{array}$ \\
\hline & & & & & Require new house \\
\hline
\end{tabular}

\section{SKETCH OF DAMAGE AND LOCATION}

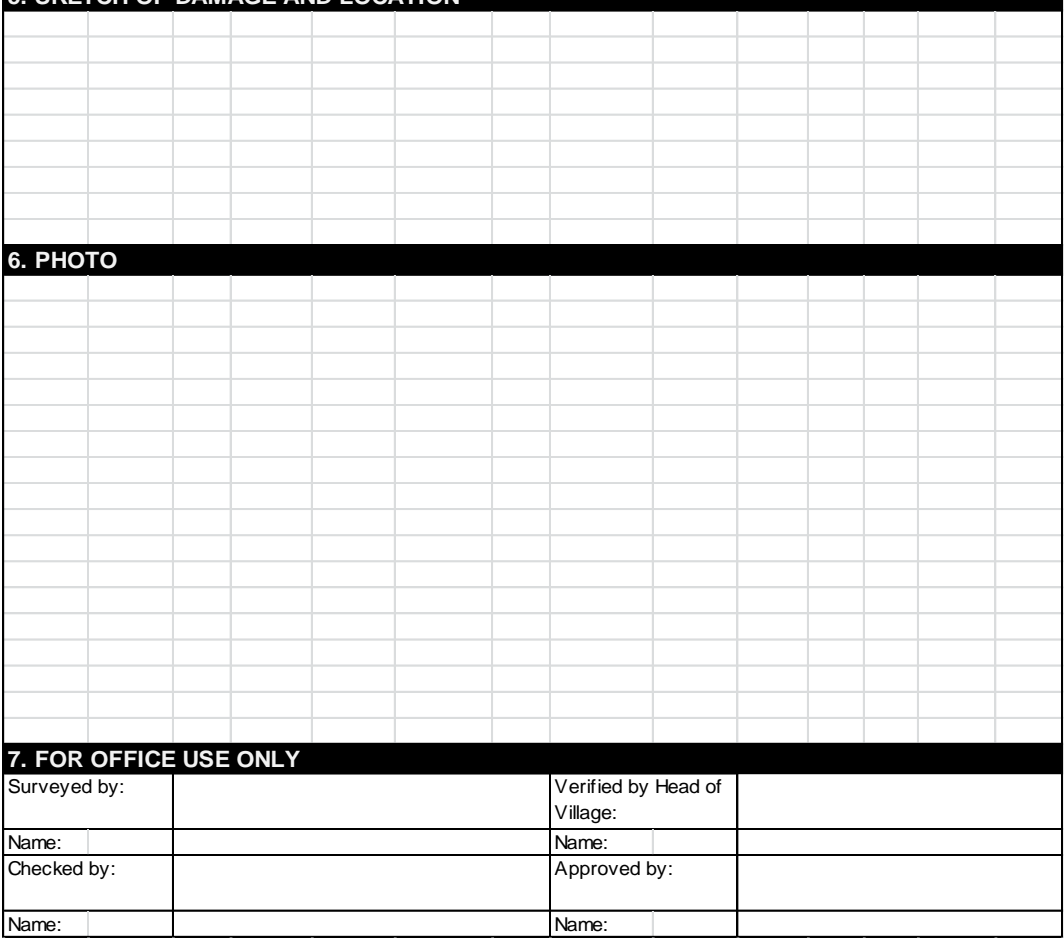

Figure 1: Housing Damage Assessment Form

(Source: Researchers' Study, 2015)

\subsection{Findings and Discussions}

In order to produce a relevant, easy to understand and user-friendly housing damage assessment form, the researchers conducted focus groups sessions among selected panels to review and provide personal views on the proposed housing damage assessment form. These focus groups consist of five (5) technical experts who are involved in MERCY Malaysia 
to assess the housing damage after a disaster. From the experts' feedback on the damage assessment form, all respondents stated their support on the items in the form. However, they commented that "declaration of accuracy" was unnecessary because verification by the Head of Village is adequate.

Below are the excerpts from the panel members:

"...Declaration of Accuracy by the house owner is not advisable because the assessment will be conducted by professionals. Verification by Head of Village is sufficient." (n1; n2)

"...Verified by Head of Village/ Representative is enough." (n3; n4)

"...Declaration of accuracy is unnecessary; the form verified by representative or head of village is sufficed." (n5)

Based on the review of literature and significant feedback from the technical experts, the design and construction of this form, the suggested Housing Damage Assessment Form after form validation is provided in Figure 1.

The Housing Damage Assessment Form will be divided into seven (7) sections (refer to Figure 1) which are Section 1 as the Incident Details that consists of information regarding the type and location of the disaster (Disaster Type, State, District, Village, Longitude, Latitude and Elevation). Section 2 is Respondent Details to identify the victim of the affected house; the details required are name, gender, marital status, contact number, age, occupation, national identity card and household information. Section 3 is Land Details, consists of information of the house status (owned or rented) and home ownership (single, multiple, rental, corporate or government). Section 4 is the Damage Assessment. In this section, the degree of housing damage model for the affected house is based on the empirical research conducted earlier which is titled "A Model to Determine the Degree of Housing Damage Assessment for Flood Affected Area in Kuala Krai, Kelantan". This section contains the degree of housing damage model and type of assistance for the affected house (Immediate action for Building Repair's Kit, Require temporary shelter, Require Permanent House).

The model is categorized into three (3) degrees of damage; 1) 'Minor' 2) 'Major' and 3) 'Destroyed'. In the event of 'Minor' degree of damage, the damage is described as slight damage to building structures; however the building can still be occupied after some minor repairs which should take less than 30 days. The attributes of damage are minor damage in partitions, infills, ceilings, doors and windows. It is recommended for immediate action in providing Building Repair's Kit type of assistance. For 'Major' degree of damage, the building has sustained structural or significant damages and can only be inhabitable after extensive repairs which require more than 30 days. The attributes of damage are substantial failure of walls, floors, foundation or roof and utilities damaged (Electrical, Surface water drainage and Sewerage reticulation). It is recommended that temporary shelter for assistance be given urgently. The last degree of damage is 'Destroyed'. The description of damage is the building 
has experienced a total loss or has been completely destroyed. The attribute of damage is total loss and unsafe for occupancy. It is recommended that temporary shelter be provided urgently and a permanent house is required. The next section is "Sketch of Damage and Location" under Section 5. This section allocates space to the assessor to sketch the location and damage sustained by the affected house. Section 6 provides space to attach the photographs of the affected house. Lastly, Section 7 provides information of the person involved in the assessment for record purposes (Surveyed by, Checked by, Verified by Head of Village and Approved by).

Next, the assessment form is used to identify the degree of housing damage at the selected area. The study area includes Jalan Geale B, Geale C, Geale C2, Geale C3, Geale C4 and Geale D located in the District of Tualang territories. Observation on the damaged houses was conducted and the total number of houses involved was 223.

Table 1: Summary of Housing Damage Degree

\begin{tabular}{|c|c|c|c|c|c|}
\hline \multirow{2}{*}{ Affected Area } & \multicolumn{5}{|c|}{ Number of houses/ Damage Scale } \\
\cline { 2 - 6 } & No Damage & Minor & Major & Destroyed & $\begin{array}{c}\text { Total of } \\
\text { houses }\end{array}$ \\
\hline $\begin{array}{c}\text { Jalan Geale } \\
\text { B }\end{array}$ & 17 & 10 & 10 & 14 & 51 \\
\hline Jalan Geale C & 0 & 5 & 7 & 15 & 27 \\
\hline $\begin{array}{c}\text { Jalan Geale } \\
\text { C2 }\end{array}$ & 3 & 10 & 9 & 9 & 31 \\
\hline $\begin{array}{c}\text { Jalan Geale } \\
\text { C3 }\end{array}$ & 6 & 8 & 1 & 5 & 20 \\
\hline $\begin{array}{c}\text { Jalan Geale } \\
\text { C4 }\end{array}$ & 15 & 18 & 18 & 3 & 54 \\
\hline Jalan Geale D & 26 & 10 & 1 & 3 & 40 \\
\hline Total & $\begin{array}{c}67 \\
(30 \%)\end{array}$ & $\begin{array}{c}61 \\
(27 \%)\end{array}$ & $\begin{array}{c}46 \\
(21 \%)\end{array}$ & $\begin{array}{c}49 \\
(22 \%)\end{array}$ & $\begin{array}{c}223 \\
(100 \%)\end{array}$ \\
\hline
\end{tabular}

(Source: Researchers' Study, 2015)

The above table indicates that the scale of damage for the houses located at the flood affected area. From the Table, it can be seen that for Jalan Geale B, 17 units or $33.3 \%$ of the houses were considered as 'No Damage' or not affected by the flood. This is followed by 14 houses or $27.5 \%$ which were Destroyed during the flood while another 20 units of remaining houses were categorized as 'Minor' and 'Major damage'. Besides that, $18.5 \%$ or 5 units of houses located at Jalan Geale $C$ were classified as 'Minor damage', while 7 houses or 25.9 $\%$ were recorded as 'Major damage'. The houses that were categorised as 'Destroyed' showed the highest with a number of 15 units or $55.6 \%$. However, there were no units of houses that were recorded as 'No Damage in this area'. The highest number of houses damaged were classified as 'Minor damage' with 10 houses or $32.3 \%$ while for 'Major 
damage' and 'Destroyed' showed the same number, 9 or $29 \%$ respectively for Jalan Geale C2. Besides that, 3 units of houses or $9.7 \%$ were recorded as 'No Damage'. There are 20 units of houses, which have been selected in determining their scale of damage in Jalan Geale C3. Six (6) units of houses were considered as 'No Damage' while another 8 units or $40 \%$ were classified as 'Minor damage'. 'Major damage' showed the lowest with one unit. The number of houses that were recorded as 'stroyed' was 5 units. 54 units of houses located at Jalan Geale C4 were observed. From the Table, it showed that 15 units of houses or $27.8 \%$ were marked as 'No Damage' while another 18 units were considered as 'Minor damage'. In terms of 'Major damage', 18 units of houses were identified and the remaining of 3 units or $5.6 \%$ were marked as "Destroyed'. In Jalan Geale D, there were 26 units of houses which were identified as 'No damage' while another 10 units were classified as 'Minor damage'. The lowest number of houses represented 'Major damage' with one unit while 3 houses were grouped as 'Destroyed'. As a conclusion, based on Table 1, attributes for 'Minor damage' recorded as highest degree of house damage with $27 \%$ (61 units houses), followed by 'Destroyed' with 22\% (49 units houses) and the remaining 21\% (46 units houses) is 'Major'. Meanwhile, 67 units or $30 \%$ of houses identified as 'No damage'.

\subsection{Conclusion}

There are many different types of assessment that may be carried out in the aftermath of a flood including housing damage assessment. This kind of assessment can be used to analyse the impact of the flood on residential communities, living quarters and land use for housing. The information obtained through this process will help plan for the re-occupancy of homes while the technical information on the type of damage will help inform the methods of repair and re-instatement and resources (equipment, manpower, and time) needed. Individual property surveys must be undertaken to provide detailed information for record or administrative purposes (tenure of property and damage category) and for technical purposes (type of construction and materials, details of damage, reinstatement steps). This information is best recorded on a standardized survey form to ensure consistency and completeness of the information collected. In carrying out the survey, attention should be paid to the depth of flooding as this will influence the extent of the damage to buildings, which may require specialist works, and in some cases, the entire demolition of the building. Therefore, this research presents an innovation of a Housing Damage Assessment Form. The Housing Damage Assessment Form will be give an edge to the government, local authorities, NGOs, MERCY, insurers or other appropriate bodies involved in assessing or evaluating the condition of houses affected by floods. By using this form, the process of assessing the degree of housing damages after floods can be more accurate, transparent, and efficient. Besides, the form provides an easier and quicker method of recording damage.

\subsection{Further Research}

The finding of this research indicates that there are some houses that were 'destroyed' and 
require new house. The government has taken the initiative to rebuild new homes for the victims. However, up to now in Kuala Krai there were only $40 \%$ of houses have been built and the remaining new homes are still in delay because the victims were unable to provide evidence of land ownership. Thus, further research needs to be carried out focusing on identifying the issues related to the delay of permanent houses construction due to land ownership constraints among the flood victims in Kuala Krai, Kelantan; and to suggest appropriate solutions to solve the issues.

\section{Acknowledgement}

The researchers would like to extend gratitude to Ministry of Education of Malaysia for granting us funding under Fundamental Research Grant Scheme (FRGS) to venture into this research and for unwaveringly supportive throughout the term of the research. Our appreciation also goes to MERCY Malaysia for their cooperation in providing critical data to enable us to carry out this research successfully. Finally, most importantly we exprss our deepest gratitude to all the respondents involved for giving their time to complete the questionnaires, interview and focus group session.

\section{References}

BNPB,B.N. (2009). West Sumatra and Jambi Natural Disaster:Damage, Loss and Preliminary Needs Assessment. Jakarta: Bappenas

Chan, N. W. (1995). Flood disaster management in Malaysia: an evaluation of the effectiveness of government resettlement. Disaster Prevention and Management: An International Journal, Vol. 4 Iss 4, 22-29.

Earthquake Engineering Field Investigation Team (EEFIT). (2003). Earthquake Engineering Field Investigation Team. Japan.

Eves, C., Wilkinson S, J. (2014). Assessing the Immediate and Short Term Impact of Flooding on Residential Property Participant Behaviour. Natural Hazards DOI 10.1007/s11069-013-0961-y

European Macroseismic Scale (EMS-98). (1998). Classification of Damage Scale.

Federal Emergency Management Agency (FEMA). (2005). Preliminary Damage Assessment for Individual Assistance: Operations Manual. United States of America.

Division of Emergency Management of Florida. (2004). Handbook for Disaster Assistance. Tallahassee: State of Florida.

Hodde, B. H. (2012). The Damage Assessment Process: Evaluating Coastal Storm Damage Assessments in Texas After Hurricane IKE. Ann Arbor: ProQuest LLC 2013.

Shah, A., Khan, H. M., \& Qazi, E. U. (2013). Damage Assessment of Flood Affected Mud Houses in Pakistan. Journal of Himalayan Earth Sciences, 99-110.

www.GreenAlert.net. (2004). Damage Assessment Manual by www.GreenAlert.net. www.GreenAlert.net. 
Mohd. T., et.al. / Asian Journal of Quality of Life (AjQoL), 3(11) May / Jun 2018 (p.47-57)

www.statistics.gov.my. (2015). Censuses and Surveys for Population and Demographic. Retrieved September 29, 2015 from

https://www.statistics.gov.my/index.php?r=column/cone\&menu_id=ZHJIbWFBSTVEcHY1ait6akR3WmtVUT09. 